\title{
The Vascular Supply of Hip Joint and its Clinical Significant
}

\author{
Suministro Vascular de la Articulación de la Cadera y su Significado Clínico
}

\author{
Waseem Al-Talalwah"***
}

\begin{abstract}
AL-TALALWAH, W. The vascular supply of hip joint and its clinical significant. Int. J. Morphol., 33(1):62-67, 2015.
SUMMARY: The hip joint gains its vascular supply from the superior gluteal arteries as well as from the medial and lateral circumflex femoral arteries with the first perforating artery. In gluteal trauma, the superior and inferior gluteal artery may be affected which may end with vascular insult of hip joint. The current study includes a dissection of 171 cadavers to examine the vascular supply of hip joint. In $99.3 \%$ of articular branch arises from the superior gluteal artery either directly or indirectly (95.4\% or in 3.9\%, respectively). In $81 \%$ of articular branch arises from the inferior gluteal artery either directly or indirectly in $78 \%$ or in $3 \%$. In $20.3 \%$ of articular branch arises from the coexistence of sciatic artery either directly or indirectly $(17.7 \%$ or in $2.6 \%$, respectively). Infrequently, the internal pudendal artery gives articular branch in $0.4 \%$. Further, there is no difference between male and female in hip joint supply in current study. Based on current study's result, the dominant articular branch of vascular supply of the hip joint comes from the superior gluteal artery whereas the inferior gluteal artery comes beyond due its congenital absence. The coexistence sciatic artery is a replacement artery for superior or inferior gluteal artery in case of congenital absence. Due to aneurysm of the three previous arteries after trauma, it is important to study their course and articular branches to avoid iatrogenic fault of joint vascular insult during surgical management of either true or false aneurysm.
\end{abstract}

KEY WORDS: Superior gluteal artery; Gluteal artery; Sciatic artery; Hip; Inferior gluteal artery; Persistent axial artery; Gluteal trauma; Iatrogenic fault of joint; Gluteal aneurysm, Rami comes nervi ischiadici; Articular branch.

\section{INTRODUCTION}

Historically, the superior gluteal artery is known as gluteal superior or gluteal artery (Gray, 1867) is classified as a third class by Herbert in 1825. The SGA is a largest and thickest branch of the internal iliac artery which is a continuation of its posterior trunk (Gray). In fact, the superior gluteal artery has three courses. First course, it is a short and tortuous intrapelvis course passing through the lumbosacral and first sacral root of the sciatic nerve. Second course, it passes superior to the piriformis through suprapiriformis foramen to exist the pelvis (Gray). Therefore, the superior gluteal artery may be injured by ridge bone of greater sciatic notch in case of posterior pelvic fracture (Batt et al., 2006). The third course, it passes in gluteal region and divides into superficial and deep branches. In gluteal region, the superior gluteal artery gives superficial and deep branch. The superficial branch runs deep to the Gluteus maximus which divides ascending and transverse branches and anastomose with the inferior gluteal and lateral sacral arteries. The deep branch runs between gluteus medius and minimus and divides into superior and inferior divisions. The superior division ascends beside the superior border of the Gluteus minimus in the direction of the anterior superior spine of the ilium which anastomose with the lateral femoral circumflex and deep iliac circumflex arteries. The inferior division runs inferio-laterally over the gluteus minimus in the direction of the greater trochanter which anastomoses with the lateral femoral circumflex artery and with medial femoral circumflex artery to supply the hip joint (Gray).

Historically, the inferior gluteal artery is known as sciatic artery. The inferior gluteal artery is a prominent terminal branch of the anterior trunk of internal iliac artery. In fact, the inferior gluteal artery has three courses. The first course is a pelvic course in which the inferior gluteal artery passes the pelvic cavity (Gray). The second course is the inferior gluteal artery passing the infrapiriformis canal to

\footnotetext{
" King Abdullah International Medical Research Center, King Saud bin Abdulaziz University for Health Sciences, College of Medicine, Department of Basic Medical Sciences, Riyadh, Kingdom of Saudi Arabia.

** Hospital, National Guard Health Affairs Ministry of National Guard, Riyadh, Kingdom of Saudi Arabia.
} 
exist from pelvic cavity. The third course is gluteal course in which the inferior gluteal artery begins between the dorsal surface of coccygeus and piriformis and distributes three branches (Gray). Based on the Herbert classification in 1825, the inferior gluteal artery divides into "ramus coccygeus", "rami glutei" and "rami comes nervi ischiadici". The inferior gluteal artery runs deep gluteus maximus, below the lower boarder of the piriformis and upper boarder of superior gemmileus (Lawton, 1965) and between greater trochanteric and ischial tuberosity (Gray). The inferior gluteal artery provides perforating branches to gluteal maximus and external rotators which anastomoses with the superior gluteal and internal pudendal arteries respectively. Further, it anastomoses with obturator and superior perforating (first perforating) as well as medial and lateral circumflex femoral artery (Gray).

The persistent sciatic artery was first described by Green on post-mortem in 1832. Anatomically, the prolongation branch of the inferior gluteal artery, referred as the sciatic artery or "comes nervi ischiadici,"stated by (Schafer \& Thane, 1892) and described as a long slender vessel by Testut \& Latarjet (1929) and Brash (1951). The sciatic artery has several names the persistent sciatic, axial, ischiatic or ischiopopliteal arterial trunk (Papon et al., 1999). Due to coexistence of the sciatic artery with the inferior gluteal artery, this is against the embryologic theory (Sidway, 2005). Therefore, the persistence of sciatic artery is not inferior gluteal artery according to this study anatomically. The sciatic artery is a tortuous path (Savov \& Wassilev, 2000) dividing into three courses. The first course is pelvic course in which the sciatic artery is a direct continuation of the internal iliac artery passing pelvic cavity reaching the pelvic floor. The second course is the sciatic artery passing the greater sciatic foramen (Kritsch et al., 2006) through the infrapiriform foramen (Jung et al., 2005). The third course is the sciatic artery starts from the dorsal surface piriformis, accompanies the sciatic nerve to the knee and projects midway between the greater trochanter and the ischial tuberosity to become the popliteal artery (Bower et al., 1977). Embryologically, the vascularity of the lower limb is initially awarded by the sciatic artery during the first trimester. By the sixth week, the external iliac/iliofemoral system arises and joins the sciatic system at the popliteal artery. As the sciatic artery system regresses, the proximal division persists as the superior and inferior gluteal arteries and distal division persists as the popliteal artery and its bifurcations (Sidway). The possibility of the sciatic artery giving branches has been proposed by Yazama et al. (2002). With variations in the persistent sciatic artery there are variations of the popliteal artery. Therefore, the coexistence of the sciatic artery effects the distribution of the vascular supply to the hip joint which has been considered in present study.

\section{MATERIAL AND METHOD}

In current study, it includes 342 gluteal regions of 171 cadavers investigating the incidence and course of the articular branch of superior and inferior gluteal arteries in relation to piriformis. The gluteal region has been dissected to trace the gluteal arteries arising from the internal iliac artery passing through the greater sciatic foramen either above or below piriformis. Previous to dissection of gluteal region, the sacrum, ischial tuberosity and greater trochanter of the femur were used as landmarks to make an incision and get rid of the skin and subcutaneous tissue. Then, an incision was made over gluteus maximus following an imaginary line starting from the sacrum and curving over the terminal part of the outer lip of the iliac crest. The sacrotuberous ligament was identified by palpation to avoid dissection during the gluteus maximus dissection. After reflection of gluteus maximus, the superior and inferior gluteal artery appears. As soon as gluteus maximus was bisected and reflected, the piriformis was identified and the gluteal arteries course traced in relation to the muscle. To determine the variability of articular branches of gluteal arteries, the upper and lower edge of piriformis has to be determined in relation to them. The superior gluteal artery give articular branch run above or deep to piriformis therefore the course has to be observed carefully. Further, the ischial spine and sacrospinous ligament were identified to find the internal pudendal artery. The internal pudendal artery and inferior gluteal artery branches were followed. The internal pudendal artery usually gives no branches in the gluteal region, except in a few cases it may give articular branch. Careful observation was made of these branches because the articular branch may arise from the internal pudendal artery. The inferior gluteal artery usually gives three branches: coccygeal, articular and ischiadic branches. The inferior gluteal artery arises lateral to the internal pudendal artery and medial to the sciatic nerve. Observations of the articular branch arising from the sciatic artery artery during its course in relation to piriformis and sciatic nerve were recorded.

\section{RESULTS}

Current study includes a dissection of 342 specimens of 171 cadavers to investigate the vascular supply of hip joint. The superior gluteal artery gives articular branch in $99.3 \%$ arising either directly in $95.4 \%$ or indirectly in $3.9 \%$. It is congenital absent in $0.7 \%$. The inferior gluteal artery gives articular branch in $81 \%$ arising either the directly in $78 \%$ or indirectly in $3 \%$. It is congenital absent in $19 \%$. The 
sciatic artery gives articular branch in $20.3 \%$ arising either directly in $17.7 \%$ or indirectly in $2.6 \%$. It is congenital absent in $77.7 \%$. It passes above and below piriformis in $0.7 \%$ and in $19.6 \%$ as well as it passes ventral and dorsal the sciatic nerve in $4.0 \%$ and in $16.3 \%$. Rarely, the internal pudendal artery gives articular branch in $0.4 \%$ (Table I).

Current study considers the investigation of vascular supply in male and female. The current study investigates vascular supply of hip joint in 158 specimens of 79 female cadavers. The superior gluteal artery gives articular branch in $98.6 \%$ arising either directly $95.2 \%$ or indirectly in $3.4 \%$. It is congenital absent in $1.4 \%$. The inferior gluteal artery gives articular branch in $78.8 \%$ arising either directly in $77.4 \%$ or indirectly in $1.4 \%$. It is congenital absent in $21.2 \%$. The sciatic artery gives articular branch in $20.3 \%$ arising either directly in $15.7 \%$ or indirectly in $4.6 \%$. It is congenital absent in $77.7 \%$. It passes above and below piriformis in $1.4 \%$ and in $18.9 \%$ as well as it passes ventral and dorsal the sciatic nerve in $4.9 \%$ and in $15.4 \%$ (Table I).

Further, the current study investigates vascular supply of hip joint in 184 specimens of 92 male cadavers. The superior gluteal artery gives articular branch in $100 \%$ arising either directly in $96.6 \%$ or indirectly in $4.4 \%$. The inferior gluteal artery gives articular branch in $82.8 \%$ arising either directly in $78.4 \%$ or indirectly in $4.4 \%$. It is congenital absent in $17.2 \%$. The sciatic artery gives articular branch in $20.3 \%$ arising either directly in $19.6 \%$ or indirectly in $0.6 \%$. It is congenital absent in $77.7 \%$. It passes above and below piriformis in $0.7 \%$ and in $19.6 \%$ as well as it passes ventral and dorsal the sciatic nerve in $3.2 \%$ and in $17.1 \%$. Infrequently, the internal pudendal artery gives articular branch in $0.7 \%$ (Table I).

\section{DISCUSSION}

The first true gluteal artery aneurysm has been reported by Gostigian \& Schlitt (1973). Then, series studies have been reviewed on aneurysm of superior gluteal artery by Schorn et al. (1995) and inferior gluteal artery by Keeling et al. (2008) due to trauma. There is no clear incidence of gluteal artery aneurysm (Schorn et al., 1995) but it is occurred more men than women. Based on previous studies, the superior gluteal artery is highly predisposed to aneurysm than the inferior gluteal artery (Smyth et al., 1965; Matas, 1909). Anatomically, the inferior gluteal artery and its branches are more endanger than the superior gluteal artery in trauma

Table I. Vascular supply of hip.

\begin{tabular}{|c|c|c|c|c|}
\hline \multirow{2}{*}{ Branches } & & \multicolumn{3}{|c|}{ Incidence $(\%)$} \\
\hline & & Total & Female & Male \\
\hline \multirow{6}{*}{$\begin{array}{l}\text { Superior gluteal } \\
\text { artery }\end{array}$} & 1. Articular Branch & 99.3 & 98.6 & 100 \\
\hline & Direct & 95.4 & 95.2 & 96.6 \\
\hline & Indirect & 3.9 & 3.4 & 4.4 \\
\hline & 2. Congenital absence & 0.7 & 1.4 & 0 \\
\hline & Direct & 0.7 & 1.4 & 0 \\
\hline & Indirect & 0 & 0 & 0 \\
\hline \multirow{6}{*}{$\begin{array}{l}\text { Inferior gluteal } \\
\text { artery }\end{array}$} & 1. Articular Branch & 81.0 & 78.8 & 82.8 \\
\hline & Direct & 78.0 & 77.4 & 78.4 \\
\hline & Indirect & 3.0 & 1.4 & 4.4 \\
\hline & 2. Congenital absence & & & \\
\hline & Congenital absence of Inferior gluteal artery & 14.1 & 17.4 & 11.2 \\
\hline & Congenital absence of Articular branch & 4.9 & 3.8 & 0 \\
\hline \multirow{10}{*}{$\begin{array}{l}\text { Sciatic } \\
\text { artery }\end{array}$} & 1. Articular Branch & 20.3 & 20.3 & 20.3 \\
\hline & Direct & 17.7 & 15.7 & 19.7 \\
\hline & Indirect & 2.6 & 4.6 & 0.6 \\
\hline & 2. Course in relation to sciatic nerve & & & \\
\hline & Pass ventral to sciatic nerve & 4.0 & 4.9 & 3.2 \\
\hline & Pass Dorsal to sciatic nerve & 16.3 & 15.4 & 17.1 \\
\hline & 3. Course in relation to piriformis & & & \\
\hline & Pas s superior to piriformis & 0.7 & 1.4 & 0.7 \\
\hline & Pass inferior to piriformis & 19.6 & 18.9 & 19.6 \\
\hline & 4. Congenital absence & 77.7 & 77.7 & 77.7 \\
\hline $\begin{array}{l}\text { Internal pudendal } \\
\text { artery }\end{array}$ & 1. Articular Branch & 0.4 & 0 & 0.7 \\
\hline
\end{tabular}




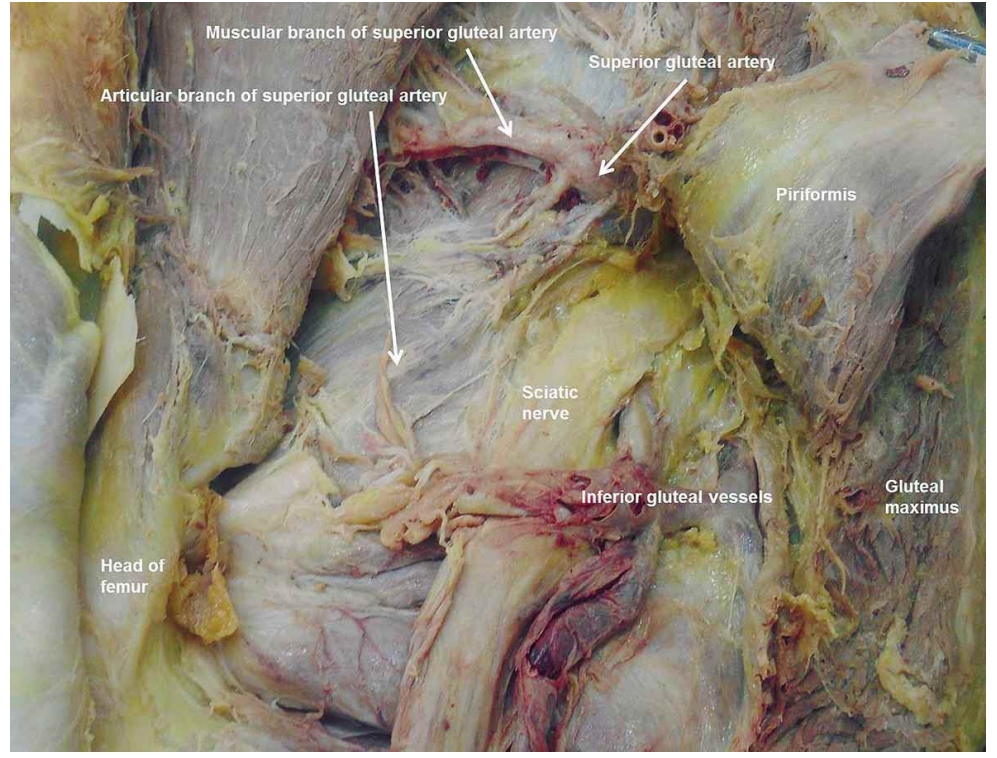

Fig. 1. The superior gluteal artery passes above the piriformis giving muscular and articular branches.

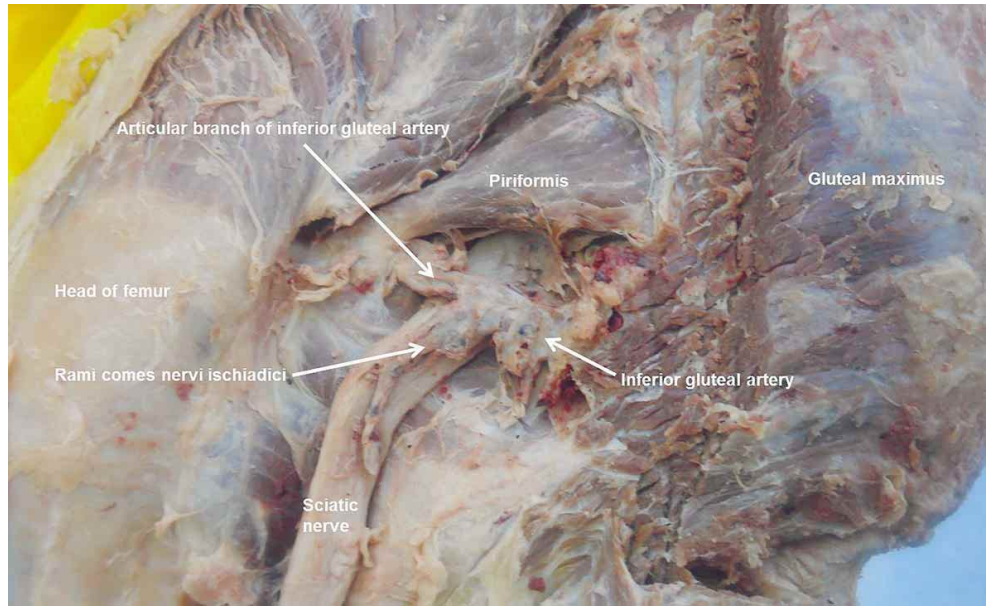

Fig. 2. The inferior gluteal artery passes below the piriformis giving sciatic (rami comes nervi ischiadici) and articular branches.

(Song et al., 2006). In current study includes the incidence of the origin variability articular branch and its course to clarify the main vascular branch of hip joint which could be endangering in trauma. The hip joint gains its supply through vascular circle formed by the superior and inferior gluteal artery and other artery (Beck et al., 2003). So, current study focused on different arteries passing the gluteal region to supply the hip joint.

As the superior gluteal artery divides, the deep branch runs between gluteus medius and minimus toward the greater trochanter to supply the hip joint (Gray). In current study, the deep branch of superior gluteal artery provides the articular branch in $98.6 \%$ classifying as a direct branch in $95.2 \%$ and indirect branch as arising from the sciatic artery in $3.4 \%$. The superior gluteal artery gives articular branch more in male than in female (Fig. 1, Table I).
The inferior gluteal artery awards articular branch to supply the hip joint with other arteries (Gray). In current study, the inferior gluteal artery provides articular branch in $81 \%$ classifying into a direct in $78 \%$ or indirect branch as arising from the sciatic artery in $3 \%$. The inferior gluteal artery gives articular branch more in male than in female (Fig. 2, Table I).

Based on embryological theory of lower limb (Sidway), the coexistence of sciatic artery may modify the vascular supply of the hip joint. The sciatic artery aneurysm was first described in 1864 ranging from $15 \%$ to $46 \%$ (Maldini et al., 2002) and occurring frequently in gluteal region (Ikezawa et al., 1994). Also, it may predispose atherosclerosis, thrombosis and peripheral vascular ischemia according to a review of series reports (van Hooft et al., 2009). Because the coexistence sciatic artery carries a high risk of hip joint vascular insult based on previous points, the current study includes this artery and its vascular supply to hip joint. In present study, the sciatic artery found to be in $20.3 \%$ which is equal in male and female. Furthermore, the sciatic artery provides articular branch in $20.3 \%$ classifying into a direct in $17.7 \%$ or indirect branch in $2.6 \%$. The direct branch of the sciatic artery is more common in male whereas the indirect branch is more common in female. The indirect branch of the sciatic artery arises from the internal pudendal artery in male and from the superior gluteal artery in female (Table I).

Series case study presented congenital absence the inferior gluteal artery (Reddy et al., 2007; Shetty et al., 2012) which could be replaced by a branch superior gluteal artery (Reddy et al.; Shetty et al.). In current study, the congenital absence the inferior gluteal artery found to be in $14.1 \%$ and its articular branch in $4.9 \%$ replaced by sciatic artery. Therefore, the articular branch is congenitally absence in $19 \%$ which is more common in female than in male. In fact, the congenital absence the inferior gluteal artery frequently occurred in female than male. In contrast, the superior gluteal artery found to be congenital absence in $0.7 \%$ occurred in female only and compensated by sciatic artery in present study. The sciatic artery is an extremely rare 
anatomical variation has been described in different clinical case report. In contrast, the congenital absent of sciatic artery is $77.7 \%$ which is equal in both sexes. Therefore, the sciatic artery found to be in $20.3 \%$ to provide sufficient supply to hip joint via articular branch to be a coexistent branch with either superior or inferior gluteal artery in entire cases. It found to be a compensatory artery in case of congenital absence of the inferior gluteal artery or its branches. Hence, the superior gluteal artery giving the anomaly branch in case of congenital absence of inferior gluteal artery (Reddy et al.; Shetty et al.) is truthfully persistent sciatic artery (Fig. 3).

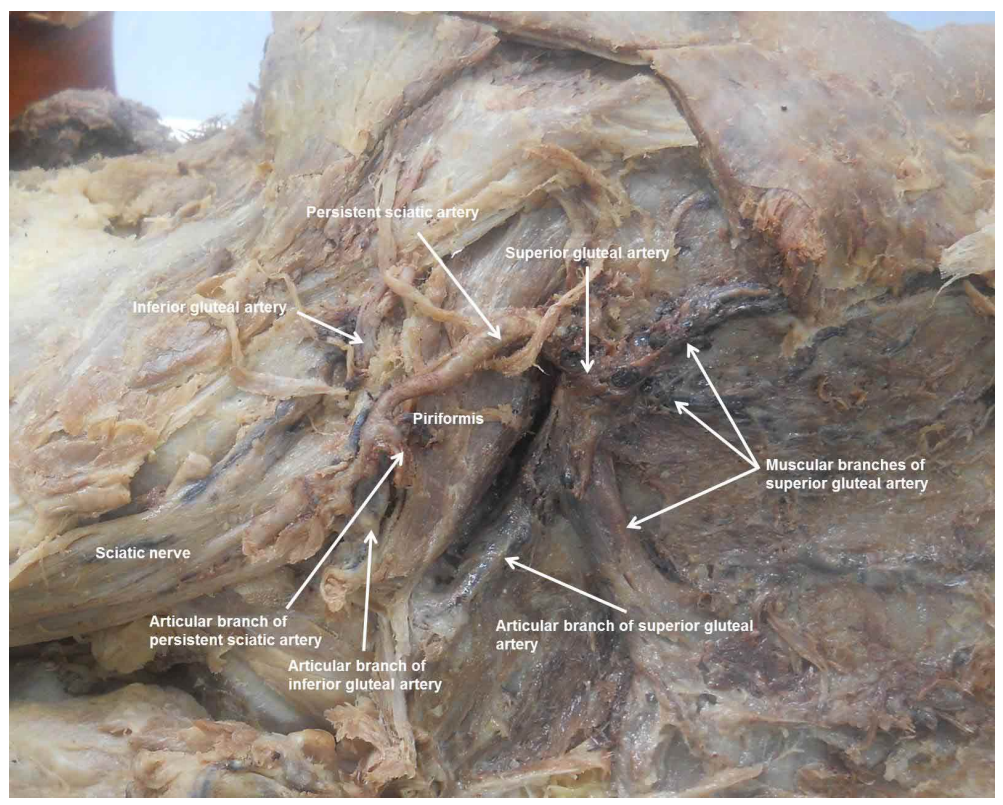

Fig. 3. The superior and inferior gluteal arteries supply the hip joint via their articular branch. In case of congenital absence of sciatic branch of inferior gluteal artery, the superior gluteal artery provides anonymous branch running over the dorsal piriformis surface and divides into sciatic branch and articular branch referred as persistent sciatic artery in current study.

\section{CONCLUSION}

The articular branch of the superior gluteal artery is a first dominant branch for vascular supply of the hip joint whereas the articular branch of the inferior gluteal artery is second dominant according to congenital absence. The articular branch of sciatic artery is a compensatory a branch in case of congenital absence of the superior and inferior gluteal arteries. The gluteal artery is a highly susceptible to blunt trauma (Batt et al.) as well as the inferior gluteal artery (Smith $e t$ al., 1976) during traversing the greater sciatic foramen. Therefore, the gluteal trauma has a high risk of hip joint vascular insult due to anatomical course and articular branches of the sciatic artery as well as the superior and inferior gluteal arteries. Further, orthopedic surgeons must have a great attention in a posterior approach of the hip joint to avoid persistent sciatic artery injury.

ACKNOWLEDGMENTS. I would like to thank Prof. Roger Soames who permits me to do this research study in Centre for Anatomy and Human Identification (CAHID). Also, I would like to thank all staffs of CAHID for providing the essential services as well as King Saud bin Abdulaziz University for Health Sciences for their support.

AL-TALALWAH, W. El suministro vascular de la articulación de la cadera y su significado clínico. Int. J. Morphol., 33(1):6-67, 2015.

RESUMEN: La articulación de la cadera obtiene su suministro vascular desde las arterias glúteas superiores, así como desde las arterias circunflejas femorales lateral y medial y la primera arteria perforante. En el trauma glúteo, las arteria glúteas superior e inferior pueden verse afectadas, lo que puede terminar con una lesión vascular de la articulación de la cadera. Este estudio incluyó la disección de 171 cadáveres con el fin de examinar el suministro vascular de la articulación de la cadera. El 99,3\% de las ramas articulares se originan de la arteria glútea superior, ya sea directa o indirectamente ( $95,4 \%$ o en 3,9\%, respectivamente). En $81 \%$ de los casos, la rama articular sse origina de la arteria glútea inferior, directa o indirectamente ( $78 \%$ y $3 \%$, respectivamente). El 20,3\% de la rama articular se origina de la conexistencia de la arteria ciática, ya sea directa o indirectamente $(17,7 \%$ y $2,6 \%$, respectivamente), y con poca frecuencia, la arteria pudenda interna origina una rama articular $(0,4 \%)$. Además, los resultados no mostraron diferencia en el suministro de articulación de la cadera entre hombres y mujeres. En base a nuestros resultados, podemos señalar que la rama articular dominante de suministro vascular de la articulación de la cadera proviene de la arteria glútea superior, mientras que la arteria glútea inferior aporta de manera escasa debido a su ausencia congénita. La coexistencia de una arteria ciática, constituye un reemplazo de las arterias glútea superior o inferior en caso de ausencia congénita. En caso de un aneurisma de alguna de las tres arterias anteriores, posterior a un trauma, resulta importante estudiar su curso y ramas articulares para evitar una lesión vascular iatrogénica conjunta durante el tratamiento quirúrgico de aneurisma de tipo verdadero o falso.

PALABRAS CLAVE: Arteria glútea superior; Arteria glútea; Arteria ciática; Cadera; Arteria glútea inferior; Arteria axial persistente; Trauma glúteo; Daño iatrogénico de las articulaciones; Aneurisma glúteo; Ramas provenientes del nervio isquiático; Rama articular. 


\section{REFERENCES}

Batt, M.; Baque, J.; Bouillanne, P. J.; Hassen-Khodja, R.; Haudebourg, P. \& Thevenin, B. Percutaneous angioplasty of the superior gluteal artery for buttock claudication: a report of seven cases and literature review. J. Vasc. Surg., 43(5):987-91, 2006.

Beck, M.; Leunig, M.; Ellis, T.; Sledge, J. B. \& Ganz, R. The acetabular blood supply: implications for periacetabular osteotomies. Surg. Radiol. Anat., 25(5-6):361-7, 2003.

Bower, E. B.; Smullens, S. N. \& Parke, W. W. Clinical aspects of persistent sciatic artery: report of two cases and review of the literature. Surgery, 81(5):588-95, 1971.

Brash, J. C. Cunningham's Textbook of Anatomy. $9^{\text {th }}$ ed. Oxford, Oxford University Press, 1951.

Gostigian, J. \& Schlitt, R. J. Aneurysm of the guteal artery secondary to polyarteritis nodosa. Am. J. Surg., 105:267-8, 1973.

Gray, H. Anatomy, descriptive and surgical. Philadelphia, Henry C. Lea, 1867.

Ikezawa, T.; Naiki, K.; Moriura, S.; Ikeda, S. \& Hirai, M. Aneurysm of bilateral persistent sciatic arteries with ischemic complications: case report and review of the world literature. J. Vasc. Surg., 20(1):96-103, 1994.

Jung, A. Y.; Lee, W.; Chung, J. W.; Song, S. Y.; Kim, S. J.; Ha, J.; Jae, H. J. \& Park, J. H. Role of computed tomographic angiography in the detection and comprehensive evaluation of persistent sciatic artery. J. Vasc. Surg., 42(4):678-83, 2005.

Keeling, A. N.; Naughton, P. A.; Leahy, A. L. \& Lee, M. J. Traumatic inferior gluteal artery pseudoaneurysm and arteriovenous fistula managed with emergency transcatheter embolization. Cardiovasc. Intervent. Radiol., 31 (Suppl. 2):S135-9, 2008.

Kritsch, D.; Hutter, H. P.; Hirschl, M. \& Katzenschlager, R. Persistent sciatic artery: an uncommon cause of intermittent claudication. Int. Angiol., 25(3):327-9, 2006.

Lawton, R. L. Cancer chemotherapy of the gastrointestinal tract with reference to intra-arterial infusion and irradiation. Am. J. Surg., 109:47-51, 1965.

Maldini, G.; Teruya, T. H.; Kamida, C. \& Eklof, B. Combined percutaneous endovascular and open surgical approach in the treatment of a persistent sciatic artery aneurysm presenting with acute limb-threatening ischemia--a case report and review of the literature. Vasc. Endovascular Surg., 36(5):403-8, 2002.

Matas, R. Surgery of the vascular system. In: Keen, W. W. \& DaCosta, J. (Eds.). Surgery, Its Principles and Practice. Vol. 5. Philadelphia, W. B. Saunders, 1909.

Papon, X.; Picquet, J.; Fournier, H. D.; Enon, B. \& Mercier, P. Persistent sciatic artery: report of an original aneurysm-associated case. Surg. Radiol. Anat., 21(2):151-3, 1999.
Reddy, S.; Vollala, V. R. \& Rao, M. Absence of inferior gluteal artery: a rare observation. Int. J. Morphol., 25(1):95-8, 2007.

Savov, J. D. \& Wassilev, W. A. Bilateral persistent complete sciatic artery. Clin. Anat., 13(6):456-60, 2000.

Schafer, E. A. \& Thane, G. D. Quain's Anatomy. Arthrology, Myology, Angiology. London, Longmans Green, 1892.

Schorn, B.; Reitmeier, F.; Falk, V.; Oestmann, J. W.; Dalichau, H. \& Mohr, F. W. True aneurysm of the superior gluteal artery: case report and review of the literature. J. Vasc. Surg., 21(5):851-4, 1995.

Shetty, S. D.; Abhinitha, P.; Marpalli, S. \& Nayak B., S. Total replacement of inferior gluteal artery by a branch of superior gluteal artery. Int. J. Anat. Var., 5:85-6, 2012.

Sidway, A. N. Embryology of the vascular system. In: Rutherford, R. B. (Ed.). Vascular surgery. $6^{\text {th }}$ ed. Philadelphia, Elsevier, 2005.

Smith, K.; Ben-Menachem, Y.; Duke, J. H. Jr. \& Hill, G. L. The superior gluteal: an artery at risk in blunt pelvic trauma. J. Trau$m a, 16(4): 273-9,1976$.

Smyth, N. P.; Rizzoli, H. V.; Ordman, C. W.; Khoury, J. N. \& Chiocca, J. C. Gluteal aneurysm. Arch. Surg., 91(6):1014-20, 1965.

Song, W. C.; Bae, S. M.; Han, S. H. \& Koh, K. S. Anatomical and radiological study of the superior and inferior gluteal arteries in the gluteus maximus muscle for musculocutaneous flap in Koreans. J. Plast. Reconstr. Aesthet. Surg., 59(9):935-41, 2006.

Testut, L. \& Latarjet, A. Traite D'Anatomie Humaine. Tome Deuxieme, Angeiologie, Systeme Nerveux Central. $8^{\text {th }}$ ed Paris, Gaston Doin \& Cie., 1929.

van Hooft, I. M.; Zeebregts, C. J.; van Sterkenburg, S. M.; de Vries, W. R. \& Reijnen, M. M. The persistent sciatic artery. Eur. J. Vasc. Endovasc. Surg., 37(5):585-91, 2009.

Yazama, F.; Hatori, N.; Kudoh, H.; Imamura, S.; Eda, T.; Endoh, A.; Ono, M.; Sawada, H. \& Horiguchi, M. Bilateral persistent sciatic arteries in a Japanese man. Anat. Sci. Int., 77(2):128-33, 2002.

Correspondence to:

Dr. Waseem Al Talalwah

King Saud bin Abdulaziz University for Health Sciences

Department of Basic Medical Sciences

College of Medicine

P.O. Box 3660, Riyadh 11481, Mail Code: 3127

Riyadh

KINGDOM OF SAUDI ARABIA

Email: altalalwahw@ksau-hs.edu.sa

Received: 28-08-2014

Accepted: 24-12-2014 